\title{
Peran Pendidikan Anak Usia Dini terhadap Hasil Belajar Siswa Sekolah Dasar Islam Terpadu Daarul Istiqlal Deli Serdang Tahun Ajaran 2016-2017
}

\author{
Widya Masitah dan Hasrian Rudi Setiawan \\ Dosen Fakultas Agama Islam UMSU \\ (Email : widya.masitah@yahoo.co.id)
}

\begin{abstract}
ABSTRAK
Penelitian ini dilakukan di SDIT Daarul Istiqlal. Penelitian ini bertujuan untuk melihat perbedaan hasil belajar siswa antara siswa yang sebelum masuk sekolah dasar tidak mengikuti pendidikan anak usia dini dengan siswa yang sebelum masuk sekolah dasar mengikuti pendidikan anak usia dini dan melihat perbedaan hasil belajar agama islam antara siswa yang sebelum memasuki sekolah dasar tidak mengikuti pendidikan anak usia dini, siswa yang sebelum memasuki sekolah dasar mengikuti pendidikan anak usia dini Taman Kanak-Kanak dengan siswa yang sebelum masuk sekolah dasar mengikuti pendidikan anak usia dini Raudhatul Athfal. Pengumpulan data melalui nilai ujian. Pengujian yang dilakukan dengan menggunakan Uji $t$. Jika dilihat hasil belajar siswa yang berkaitan dengan mata pelajaran agama islam terbukti bahwa ada perbedaan hasil belajar agama islam antara siswa yang sebelum memasuki sekolah dasar tidak mengikuti pendidikan anak usia dini, siswa yang sebelum memasuki sekolah dasar mengikuti pendidikan anak usia dini Taman Kanak-Kanak dengan siswa yang sebelum masuk sekolah dasar mengikuti pendidikan anak usia dini Raudhatul Athfal. Hal ini terlihat dari perbedaan hasi belajar yang signifikan pada mata pelajaran praktek islam seperti praktek sholat, tahsin qur'an dan tahfiz qur'an. Hal ini dapat dibuktikan dengan hasil perhitungan Jika Sig $<\alpha=0.05$ : H1 diterimaa atau Ho diterima. Hasil perhitungan Praktek sholat 0,025 < 0.05. Hasil perhitungan Tahfis $0.001<$ 0.05. Hasil perhitungan Tahsin $0.009<0.05$.
\end{abstract}

Kata Kunci : Pendidikan Anak Usia Dini, Hasil Belajar, SDIT

Korespondensi : FAI Universitas Muhammadiyah Sumatera Utara Jalan Kapten Mukhtar Basri No. 03 Medan

\section{A. PENDAHULUAN}

\subsection{Latar Belakang Masalah}

Tahun-tahun pertama setelah seorang anak dilahirkan sering dikenal dengan anak usia dini.
Usia 0-6 tahun anak dikenal dengan istilah masa keemasan (Golden Age) dimana pada masa ini perkembangan anak cukup pesat sehingga pada masa inilah 


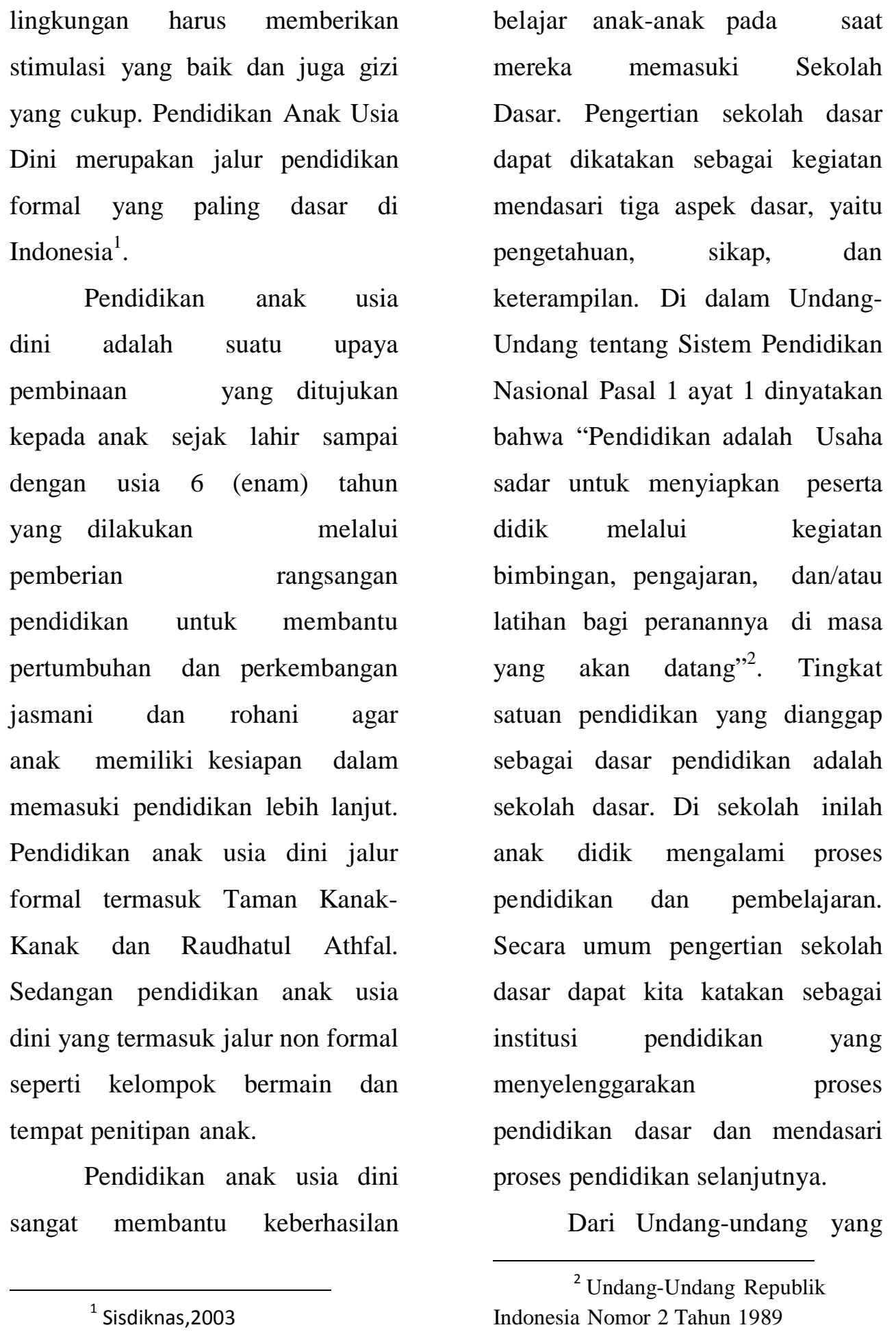




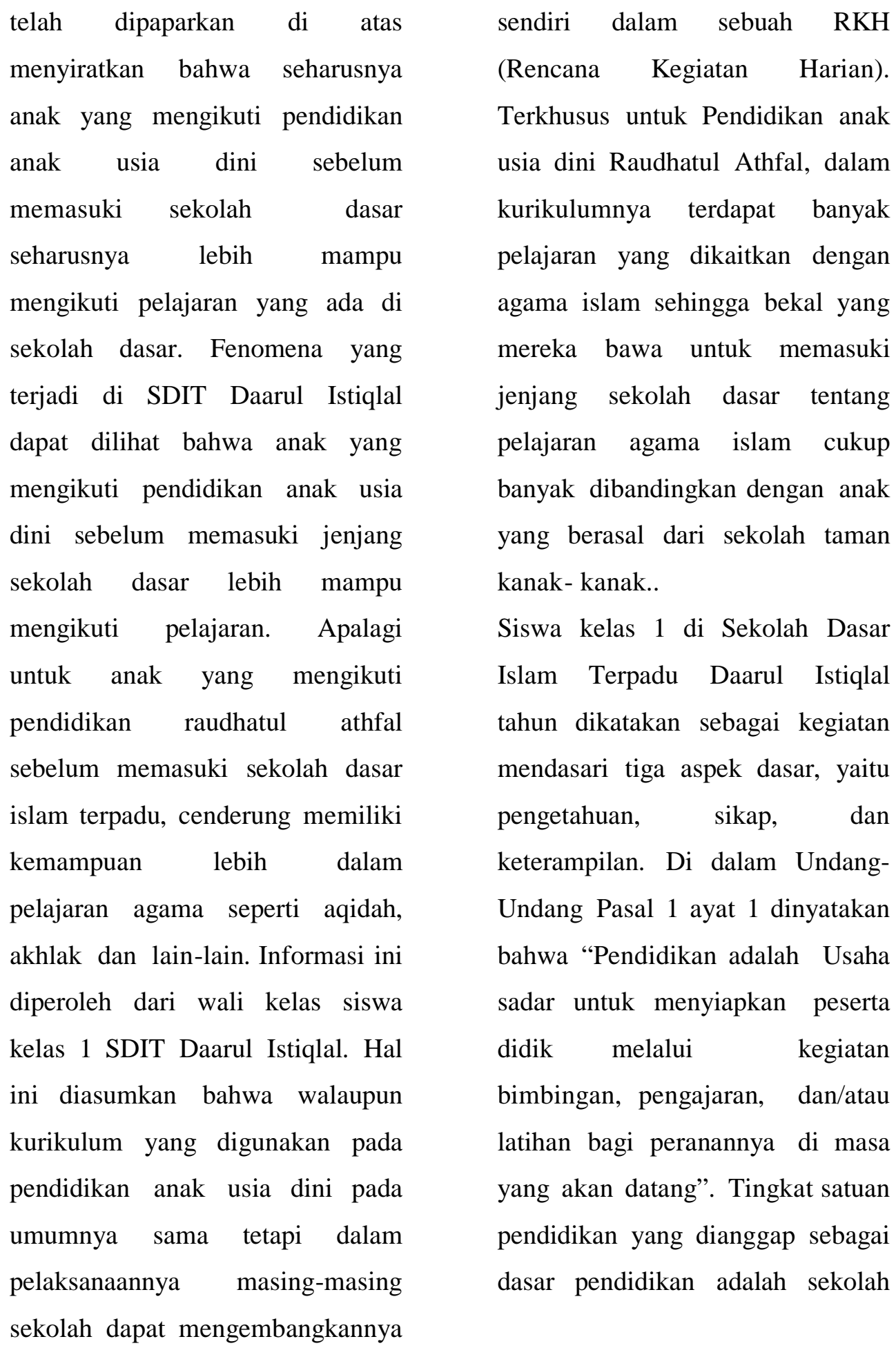




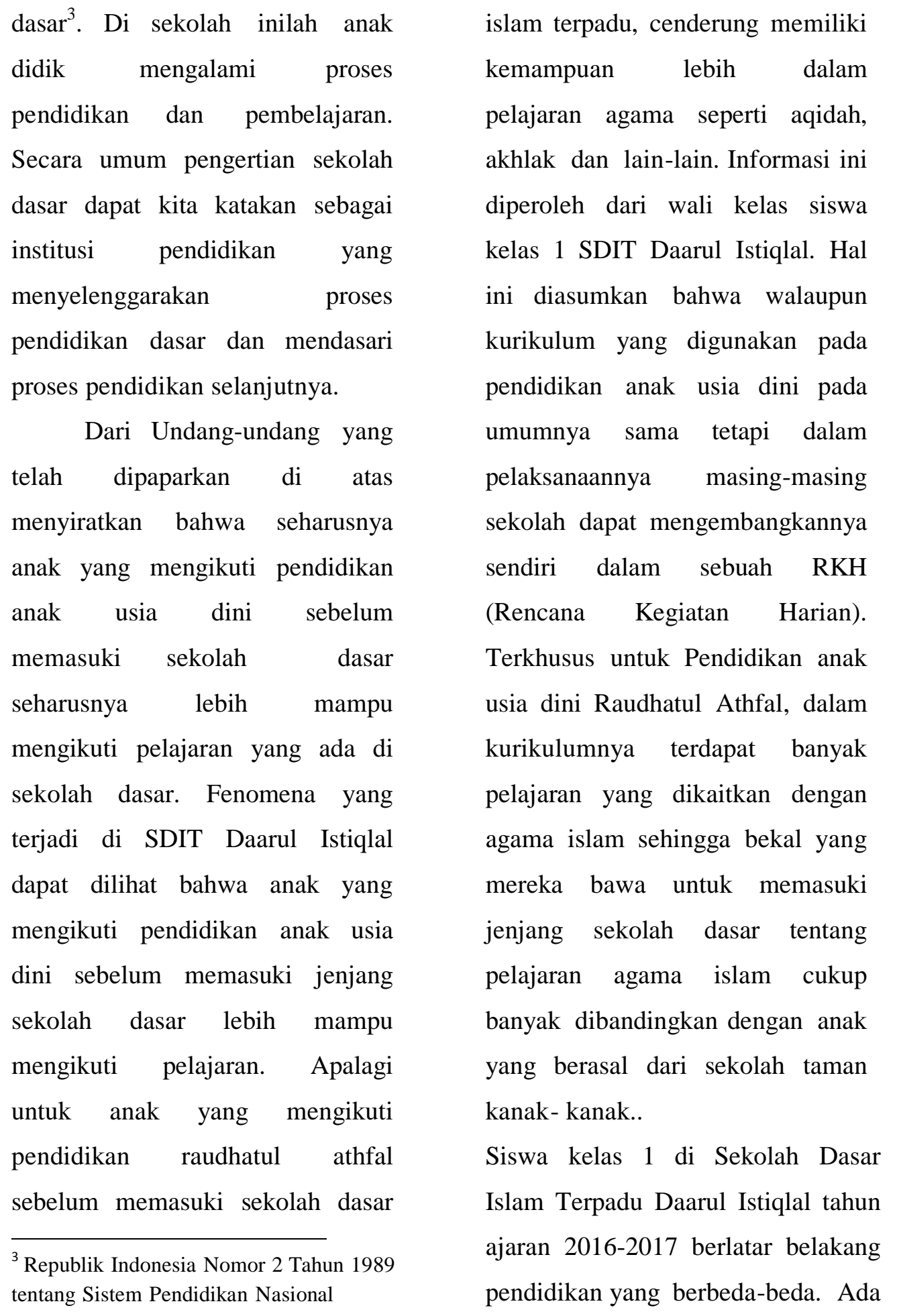


yang berasal dari raudhatul Athfal,

Taman Kanak-Kanak bahkan ada yang tidak mengikuti jalur pendidikan anak usia dini sebelum masuk ke pendidikan sekolah dasar islam terpadu. Kurikulum yang digunakan yaitu kurikulum nasional dengan pendekatan Islami melalui pengintergrasian antara pendidikan agama dengan pendidikan umum, antara sekolah, orang tua dan masyarakat dengan mengoptimalkan aspek kognitif, afektif dan psikomotorik . Dari fenomena yang telah dipaparkan di atas maka dari itu peneliti ingin melihat hasil belajar siswa-siswa tersebut terkhusus untuk hasil belajar agama islam yang tertuang dalam penelitian ini dengan judul "Peran Pendidikan Anak Usia Dini terhadap Hasil Belajar Siswa Sekolah Dasar Islam Terpadu Daarul Istiqlal Deli Serdang Tahun Ajaran 2016-2017

\subsection{Rumusan Masalah}

Rumusan masalah di dalam penelitian ini yaitu :

1. Bagaimana perbedaan hasil belajar siswa antara siswa yang sebelum masuk sekolah dasar tidak mengikuti pendidikan anak usia dini dengan siswa yang sebelum masuk sekolah dasae mengikuti pendidikan anak usia dini

2. Bagaimana perbedaan hasil belajar agama islam antara siswa yang sebelum memasuki sekolah dasar tidak mengikuti pendidikan anak usia dini, siswa yang sebelum memasuki sekolah dasar mengikuti pendidikan anak usia dini Taman Kanak-Kanak dengan siswa yang sebelum masuk sekolah dasar mengikuti pendidikan anak usia dini Raudhatul Athfal

\subsection{Hipotesis Penelitian}

Adapun hipotesis yang diajukan dalam penelitian ini yaitu :

1. Apakah ada perbedaan hasil belajar siswa antara siswa yang sebelum masuk sekolah dasar tidak mengikuti 
pendidikan anak usia dini dengan siswa yang sebelum masuk sekolah dasae mengikuti pendidikan anak usia dini.

2. Apakah ada perbedaan hasil belajar agama islam antara siswa yang sebelum memasuki sekolah dasar tidak mengikuti pendidikan anak usia dini, siswa yang sebelum memasuki sekolah dasar mengikuti pendidikan anak usia dini Taman Kanak-Kanak dengan siswa yang sebelum masuk sekolah dasar mengikuti pendidikan anak usia dini Raudhatul Athfal.

\subsection{Tujuan Penelitian}

Penelitian ini secara umum memiliki tujuan untuk melihat perbedaan hasil belajar siswa ditinjau dari pendidikan anak usia dini. Sedangkan secara khusus, penelitian ini bertujuan untuk :

1. Mengetahui perbedaan hasil belajar siswa antara siswa yang sebelum masuk sekolah dasar tidak mengikuti pendidikan anak usia dini dengan siswa yang sebelum masuk sekolah dasar mengikuti pendidikan anak usia dini.

2. Mengetahui perbedaan hasil belajar agama islam antara siswa yang sebelum memasuki sekolah dasar tidak mengikuti pendidikan anak usia dini, siswa yang sebelum memasuki sekolah dasar mengikuti pendidikan anak usia dini Taman Kanak-Kanak dengan siswa yang sebelum masuk sekolah dasar mengikuti pendidikan anak usia dini Raudhatul Athfal.

\section{B. KAJIAN PUSTAKA}

\subsection{Pendidikan Anak Usia Dini}

\section{Pengertian Pendidikan Anak} Usia Dini

Pendidikan anak usia dini (PAUD) adalah suatu upaya pembinaan yang ditujukan bagi anak sejak lahir sampai dengan usia enam tahun yang dilakukan 


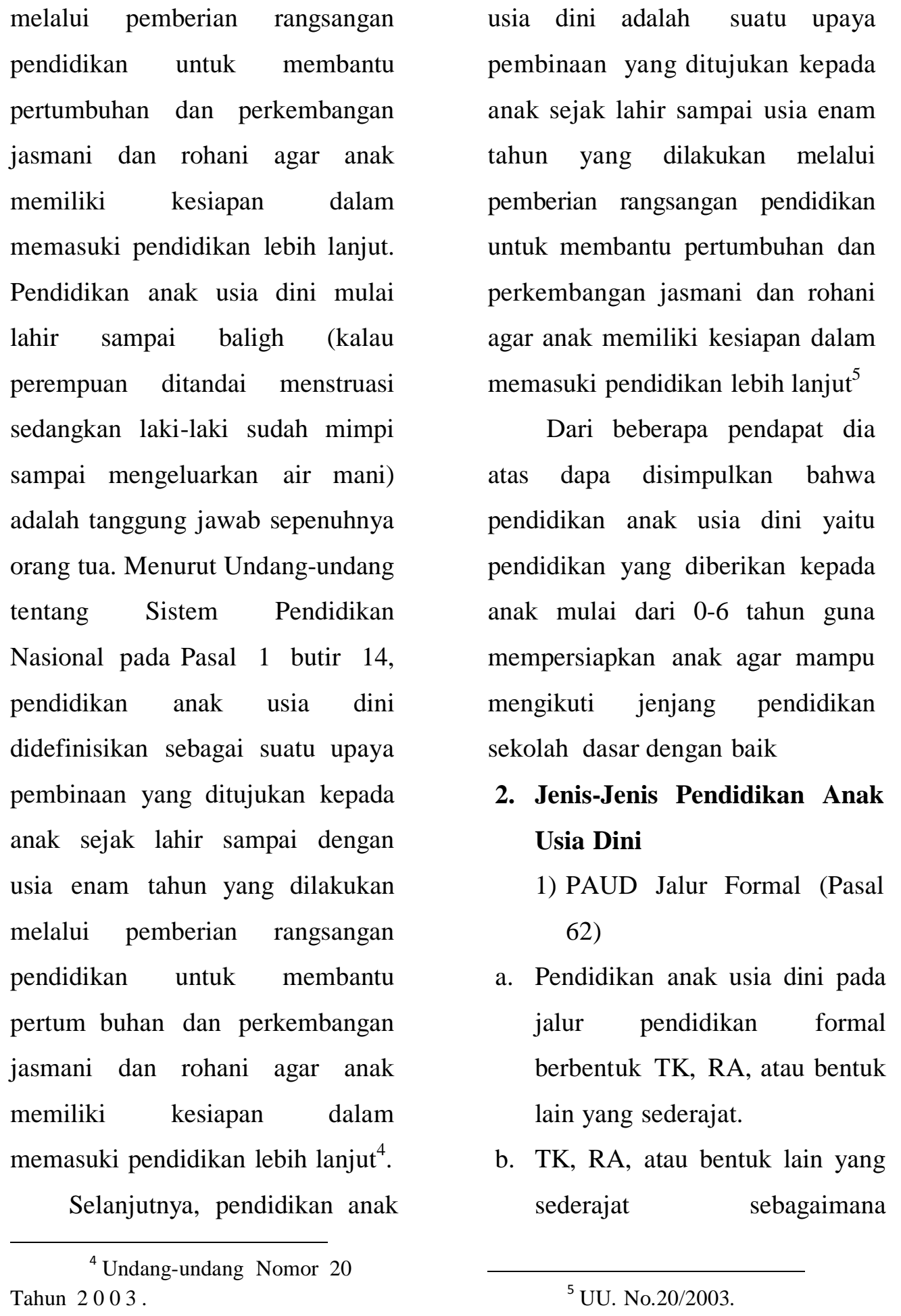




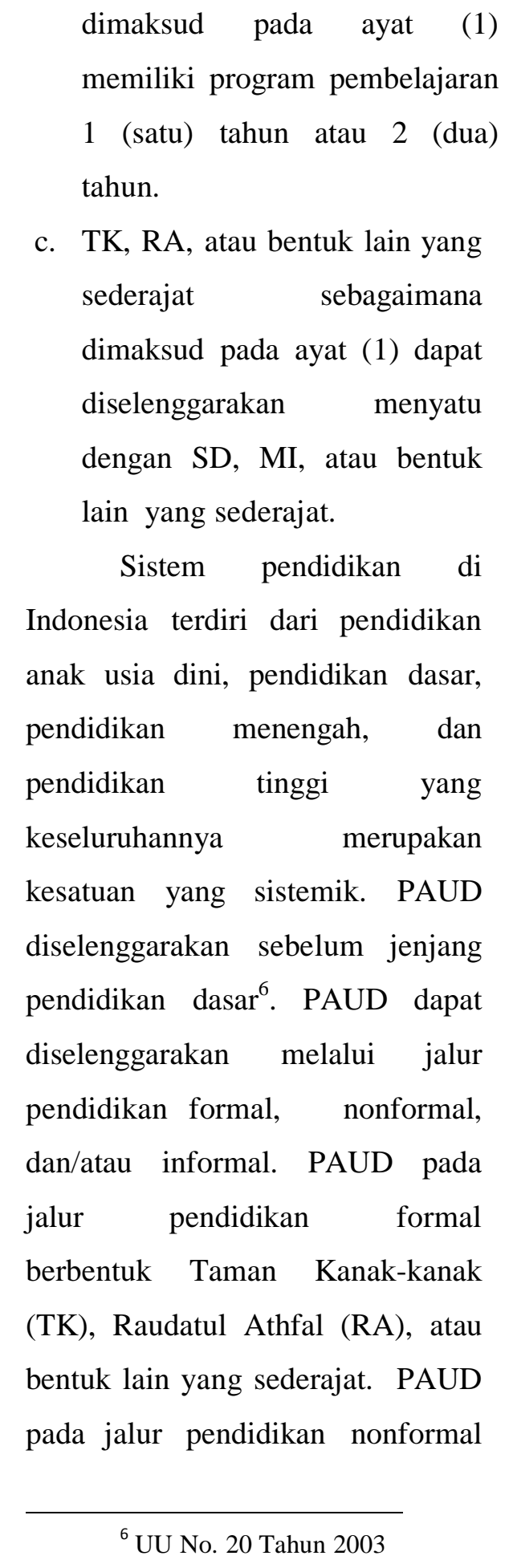
berbentuk Kelompok Bermain (KB), Taman Penitipan Anak (TPA), atau bentuk lain yang sederajat. PAUD pada jalur pendidikan informal berbentuk pendidikan keluarga atau pendidikan yang diselenggarakan oleh lingkungan.

2) PAUD Jalur Nonformal (Pasal 107)
a. Pendidikan anak usia dini pada jalur pendidikan nonformal berbentuk kelompok bermain, taman penitipan anak, dan satuan pendidikan anak usia dini yang sejenis.
b. Kelompok bermain, taman penitipan anak, dan satuan pendidikan anak usia dini yang sejenis menyelenggarakan pendidikan dalam konteks:
a) Bermain sambil belajar dalam rangka pembelajaran agama dan ahlak mulia;
b) Bermain sambil 


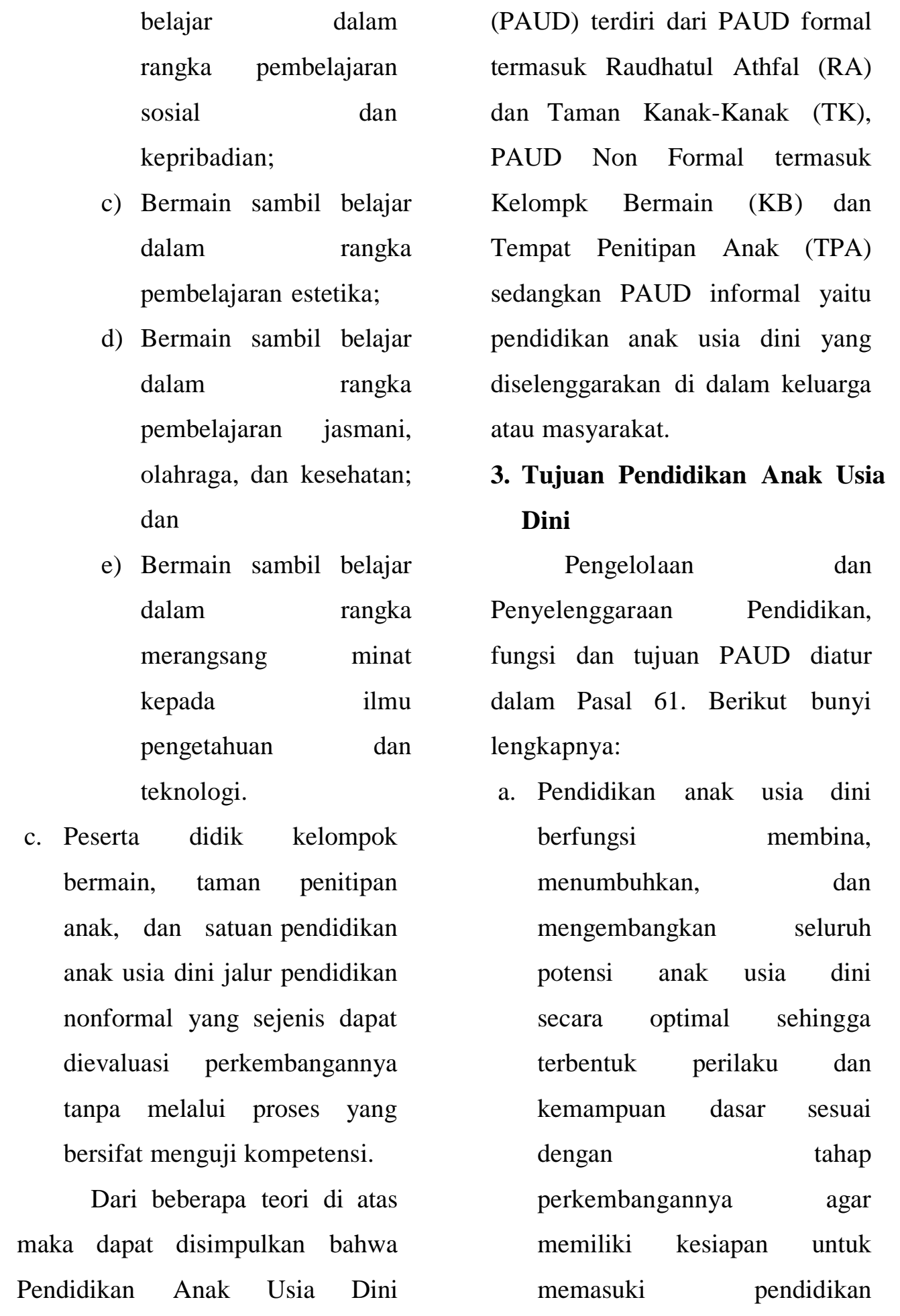


selanjutnya.

b. Pendidikan anak usia dini bertujuan:

a) Membangun landasan bagi berkembangnya potensi peserta didik agar menjadi manusia beriman dan bertakwa kepada Tuhan Yang Maha Esa, berakhlak mulia, berkepribadian luhur, sehat, berilmu, cakap, kritis, kreatif, inovatif, mandiri, percaya diri, dan menjadi warga negara yang demokratis dan bertanggung jawab; dan

b) Mengembangkan potensi kecerdasan spiritual, intelektual, emosional, kinestetis, dan social peserta didik pada masa emas pertumbuhannya dalam lingkungan bermain yang edukatif dan menyenangkan ${ }^{7}$.

\subsection{Pendidikan Sekolah Dasar}

1. Pengertian Pendidikan Sekolah Dasar

Berdasar pada amanat Undang-undang Dasar 1945,

${ }^{7}$ PP 17 Tahun 2010 maka pengertian pendidikan di sekolah dasar merupakan upaya untuk mencerdaskan dan mencetak kehidupan bangsa yang bertaqwa, cinta dan bangga terhadap bangsa dan negara, terampil, kreatif, berbudi pekerti yang santun serta mampu menyelesaikan permasalahan di lingkungannya. Pendidikan di sekolah dasar merupakan pendidikan anak yang berusia antara 7 sampai dengan 13 tahun sebagai pendidikan di tingkat dasar yang dikembangkan sesuai dengan satuan pendidikan, potensi daerah/karakteristik daerah, sosial budaya masyarakat setempat bagi siswa. Disinilah siswa sekolah dasar ditempa berbagai bidang studi yang kesemuanya harus mampu dikuasai siswa. Tidaklah salah bila di sekolah dasar disebut sebagai pusat pendidikan. bukan hanya di kelas saja proses pembelajaran itu terjadi akan tetapi di luar kelas pun juga termasuk ke dalam kegiatan pembelajaran. 


\begin{abstract}
Dari beberapa pendapat di atas maka dapat disimpulkan bahwa pendidikan sekolah dasar yaitu usaha yang dilakukan agar siswa dapat mengembangkan potensi yang ada didalam dirinya sehingga dapa membentuk intelektua, kepribadian, serta spiritual yang baik sehingga dapat hidup bermasyarakat, berbangsa dan bernegara.
\end{abstract}

\section{Tujuan Pendidikan Sekolah} Dasar

Dari kutipan Undangundang tersebut di atas sebagaimana landasannya, maka tujuan pendidikan di sekolah dasar sendiri dapat diuraikan meliputi beberapa hal yaitu:

a. Beriman dan bertaqwa terhadap TuhanNya,

b. Mengarahkan dan membimbing siswa ke arah situasi yang berpotensi positif, berjiwa besar, kritis,cerdas dan berakhlak mulia,

c. Memiliki rasa cinta tanah air, bangga dan mampu mengisi hal yang bertujuan membangun diri sendiri bangsa dan negara,

d. Membawa siswa sekolah dasar mampu berprestasi ke jenjang selanjutnya.

\section{Kurikulum \\ Pendidikan} Sekolah Dasar

Bentuk satuan pendidikan dasar 6 tahun berdasarkan kurikulum nasional diperkaya dengan pendekatan Islami melalui pengintergrasian antara pendidikan agama dengan pendidikan umum, antara sekolah, orang tua dan masyarakat dengan mengoptimalkan aspek kognitif, afektif dan psikomotorik.

Acuan Kurikulum SDIT Daarul Istiqlal yaitu :

a. Pelajaran Umum menggunakan Kurikulum DikNas 2004.

b. Pelajaran Keagamaan menggunakan Kurikulum Depag 2004 + Modifikasi.

c. Pelajaran Tahfidz Qur'an dan Ekstra Kurikuler menggunakan Kurikulum Lokal. 


\subsection{Hasil Belajar}

\section{Pengertian Hasil Belajar}

Adapun hasil belajar yang dimaksud di sini adalah kemampuan-kemampuan yang dimiliki seorang siswa setelah peserta didik menerima pelajaran dari guru selaku pendidik. Menurut Nana Sudjana (2005), hasil belajar adalah kemampuankemampuan yang dimiliki siswa setelah menerima pengalaman belajarnya.

Dari definisi di atas, dapat dipahami bahwa hasil belajar adalah merupakan hasil dan bukti belajar seseorang yang ditunjukkan dengan adanya perubahan tingkah laku. Hasil belajar akan tampak pada setiap perubahan pada aspek-aspek tersebut, baik dari salah satu aspek atau beberapa aspek. Adapun aspek-aspek tersebut adalah pengetahuan, pengertian, kebiasaan, keterampilan, emosional, hubungan soisal, budi pekerti dan sikap.
2. Faktor-faktor

Yang

Mempengaruhi Hasil Belajar

Secara umum ada dua faktor yang mempengaruhi hasil belajar yang dicapai oleh siswa, di antaranya adalah: Pertama, Faktor internal yaitu dari sisi diri peserta didik, terdapat dua hal yang dapat mempengaruhi aktivitas dan hasil belajarnya, yaitu kondisi psikologis dan fisiologis. Kondisi psikologis adalah keadaan jiwa atau ruhaninya. Sedangkan kondisi fisiologis merupakan kondisi fisik, jasmani, atau tubuh peserta didik yang belajar. Dalam hal ini kondisi psikologis peserta didik sangat berpengaruh terhadap kegiatan belajar dan hasil yang akan dicapai. Seorang peserta didik yang kurang matang secara psikologis akan mengalami kesulitan dalam memahami materi-materi pelajaran yang bersifat abstrak. Demikian pula peserta didik yang mengalami gangguan atau jiwanya tidak stabil, maka akan sulit mencapai hasil yang baik dalam belajar. 
Sama halnya dengan kondisi psikologis, kondisi fisiologis peserta didik juga akan sangat berpengaruh terhadap kegiatan belajar dan hasil yang akan dicapainya, seperti seorang peserta didik yang sedang terganggu kesehatan jasmani atau panca indranya, keadaan tersebut akan mengganggu terhadap kegiatan belajar dan hasil yang akan dicapai. Begitu pula keadaan peserta didik yang kurang gizi juga akan berpengaruh negatif terhadap aktivitas belajar dan hasil belajar yang dicapai. Kedua kondisi terebut menyebabkan fisik peserta didik menjadi lemah sehingga berpegaruh terhadap kemampuannya dalam memusatkan perhatian atau berkonsentrasi dalam belajar.

Kedua, Faktor eksternal yaitu segala sesuatu yang berasal dari luar diri peserta didik yang dapat mempengaruhi aktivitas dan hasil belajarnya. Ada dua faktor eksternal yang dapat mempengaruhi aktivitas dan hasil belajar seseorang peserta didik,
yaitu:

a. Faktor-faktor sosial.

Faktor social ini termasuklah pada pengelaman seseorang seperti pengalaman sebelum masuk sekolah dasar, seorang anak terlebih dahulu mengikuti pendidikan anak usia dini.

b. Faktor non-sosial. Faktor ini menyangkut banyak hal, seperti keadaan suhu udara, keadaan cuaca, keadaan ruangan, sarana dan fasilitas.

Dari penjelasan tersebut dapat dipahami bahwa, hasil belajar siswa dipengaruhi oleh internal, eksternal, soial dan non social.

\section{Penilaian Belajar}

Dalam membicarakan hasil belajar tidak bisa dipisahkan dari penilaian sebagai aktivitas di dalam menentukan tinggi rendahnya hasil belajar. Bila membicarakan penilaian maka 
tidak terlepas dari masalah evaluasi, sebab evaluasi merupakan suatu tindakan untuk menentukan nilai segala sesuatu di dalam pembelajaran. Evaluasi hasil belajar adalah suatu proses yang sistematis dan berkelanjutan untuk menentukan kualitas daripada sesuatu, berdasarkan pertimbangan dan kriteria tertentu untuk membuat suatu keputusan ${ }^{8}$.

Evaluasi hasil belajar adalah memberikan pelayanan atas proses pembelajaran, evaluasi sangat penting dilakukan untuk memutuskan tujuan setiap usaha. Dalam pelaksanaan evaluasi, secara umum tes hasil belajar dapat dibedakan menjadi dua macam, yaitu:

1) Tes formatif adalah tes yang diadakan sebelum atau selama pelajaran berlangsung. Tes formatif ini mempunyai dua tujuan, yaitu untuk membantu dosen dalam membuat perencanaan dan

8 Arifin, Z. (2012). Evaluasi Pembelajaran. Jakarta: Direktorat Jendral Pendidikan Islam Kementrian Agama. untuk membantu mahasiswa mengenali segi-segi yang perlu ditanggani. Tes ini disebut juga pra tes. Adapun manfaat dari tes formatif adalah untuk membantu dosen menentukan apa yang sudah diketahui mahasiswa. Kadang juga tes formatif dimanfaatkan untuk mengetahui segi-segi apa yang masih lemah ketika pengajaran sudah selesai ${ }^{9}$.

2) Tes sumatif adalah tes yang diselenggarakan pada akhir seluruh kegiatan belajar mengajar. Tujuannya adalah untuk memberi tahu dosen dan mahasiswa tentang seberapa jauh yang telah dicapai selama satu triwulan dan selama satu semester $^{10}$.

Dari kedua jenis tes hasil belajar di atas, dapat dipahami bahwa dalam pelaksanaan tes

\footnotetext{
${ }^{9}$ Purwanto, M. N. (2005). PrinsipPrinsip dan Teknik Evaluasi Pengajaran. Bandung: Rosdakarya.

10 Rosnita. (2007). Evaluasi Pendidikan. Bandung: Ciptapustaka Media.
} 
formatif maupun tes sumatif ini dilaksanakan dengan maksud untuk mendapatkan data keberhasilan pembelajaran dari bahan pembelajaran yang telah dilaksanakan, guna mengetahui pencapaian prestasi belajar hasiswa, potensi mahasiswa dan efektifitas proses interaksi pembelajaran.

\subsection{Keterkaitan Kurikulum}

\section{PAUD dengan Kurikulum}

\section{SDIT Daarul Istiqlal}

Pada dasarnya kurikulum yang digunakan di PAUD adalah sama yang berasal dari dinas pendidikan, tetapi pada pelaksanaannya di sekolah RA lebih cendurung merancang sebuah Rencana Kegiatan Harian kearah pembelajaran agama islam sedangkan di TK lebih cenderung kepada hal-hal yang umum saja. Begitu juga untuk kurikulum di sekolah dasar. Pada umumnya kurikulum yang dipakai di sekolah dasar mengacu kepada kurikulum dari dinas pendidikan tetapi banyak penambahan yang diterapkan seperti yang ditemui di SDIT Daarul Istiqlal yang memberi penambahan di bidang aqidah, ahlak, muamalah dan lain-lain.

\section{METODE PENELITIAN}

\subsection{Lokasi dan Waktu Penelitian \\ Penelitian ini dllaksanakan di SDIT Daaru Istiqlal. Penelitian ini dilaksanakn dari bulan Okober 2016 sampai Februari 2017. Penentuan waktu mengacu kepada kalender pendidikan Dinas Pendidikan}

\subsection{Populasi dan Sampel Penelitian \\ Adapun yang menjadi populasi penelitian dalam} penelitian ini adalah seluruh siswa kelas 1 SDIT Daarul Istiqlal yang berjumlah 67 orang, yang terdiri dari 31 orang perempuan dan 36 orang laki-laki.

Teknik pengabilan sampel dalam penelitian ini yaitu sensus dimana semua populasi menjadi sampel yaitu 67 orang, melihat jumlah siswa yang tidak terlalu 
banyak $^{11}$.

\subsection{Metode Penelitian}

Metode penelitian ini adalah metode penelitian kuantitatif. Metode penelitian kuantitatif yaitu metode penelitian yang berlandaskan pada filsafat positivisme, digunakan untuk meneliti pada populasi atau sampel tertentu dengan tujuan untuk menguji hipotesis yang telah ditetapkan $^{12}$

\subsection{Metode Pengumpulan Data}

Dokumentasi adalah

mencari dan mengumpulkan data mengenai hal-hal yang berupa catatan, transkrip, buku, surat kabar, majalah, notulen, rapot, agenda dan sebagainya. Dalam penelitian ini data diperoleh dari hasil ujian yang tertuang di dalam rapot siswa ${ }^{13}$.

\subsection{Teknik Analisi Data}

\section{Uji t}

\footnotetext{
11 Sugiyono, 2007, Statistika

Untuk Penelitian, Cetakan

Keduabelas. Bandung : Alfabeta

12 Ibid

13 Arikunto, S. (2006). Metodelogi penelitian. Yogyakarta: Bina Aksara
}

Uji $\mathrm{t}$ digunakan untuk menganalisis perbedaan antara 2 kelompok $^{14}$. Uji hipotesis dengan uji $\mathrm{t}$ digunakan untuk mengetahui apakah hasil belajar kelompok satu lebih baik dari pada hasil belajar kelompok 2. Hipotesis yang diajukan adalah sebagai berikut: $\mathrm{H}_{0}=\mathrm{b} 1=\mathrm{b} 2$, artinya tidak ada perbedaan hasil belajar siswa antara siswa yang sebelum memasuki sekolah dasar tidak mengikuti pendidikan anak usia dini dengan yang mengikuti pendidikan anak usia dini.

$$
\begin{aligned}
& \mathrm{Ha}=\mathrm{b} 1 \neq \mathrm{b} 2 \text {, artinya ada } \\
& \text { perbedaan hasil belajar siswa } \\
& \text { antara siswa yang sebelum } \\
& \text { memasuki sekolah dasar tidak } \\
& \text { mengikuti pendidikan anak usia } \\
& \text { dini dengan yang mengikuti } \\
& \text { pendidikan anak usia dini. }
\end{aligned}
$$

\section{Keterangan :}

$$
\begin{aligned}
\mathrm{b} 1= & \text { Siswa yang sebelum masuk } \\
& \text { sekolah dasar tidak } \\
& \text { mengikuti pendidikan anak } \\
& \text { usia dini }
\end{aligned}
$$

\footnotetext{
${ }^{14}$ Usman, Husaini, 2006. Pengantar Statistika. Jakarta : Bumi Aksara
} 


$$
\begin{aligned}
\mathrm{b} 2= & \text { Siswa yang sebelum masuk } \\
& \text { sekolah dasar mengikuti } \\
& \text { pendidkan anak usia dini }
\end{aligned}
$$

\section{One Way Anava}

One Way Anava digunakan untk menganalisis perbedaan lebih dari dua kelompok $^{15}$. Hipotesis yang diajukan adalah :

$$
\begin{aligned}
& \mathrm{H}_{0}=\mathrm{b} 1=\mathrm{b} 3=\mathrm{b} 4 \text {, artinya } \\
& \text { tidak ada } \\
& \text { perbedaan hasil } \\
& \text { belajar agama } \\
& \text { islam siswa } \\
& \text { antara siswa } \\
& \text { yang sebelum } \\
& \text { memasuki } \\
& \text { sekolah dasar } \\
& \text { tidak mengikuti } \\
& \text { pendidikan anak } \\
& \text { usia dini, yang } \\
& \text { mengikuti } \\
& \text { pendidikan anak } \\
& \text { usia dini TK } \\
& \text { dengan yang } \\
& \text { mengikuti } \\
& \text { pendidikan anak } \\
& \text { usia dini RA }
\end{aligned}
$$

\section{Keterangan :}

$$
\begin{aligned}
& \text { b1= Siswa yang sebelum } \\
& \text { masuk sekolah dasar } \\
& \text { tidak mengikuti } \\
& \text { pendidikan anak usia } \\
& \text { dini. }
\end{aligned}
$$

$$
\begin{aligned}
\mathrm{b} 4= & \text { Siswa yang sebelum masuk } \\
& \text { sekolah dasar mengikuti } \\
& \text { pendidikan anak usia dini RA. }
\end{aligned}
$$

\section{HASIL ANALISIS DAN PEMBAHASAN}

\subsection{Hasil Penelitian}

\section{Gambaran umum lokasi penelitian}

Penelitian ini dilakukan di SDIT

Daarul Istiqlal yang beralamat di jl. Pantai Rambung Gg. Cakra 5 pasar III marindal desa sigara-gara kecamatan patumbak kabupaten deli serdang medan. Sekolah ini terdri dari 12 kelas, 1 ruang guru, 1 ruang kepala sekolah dan berbagai fasilitas lainnya seperti kantin dan lain-lain.

\footnotetext{
15 Ibid
} 
Adapun tenaga pengajar yaitu satu orang kepala sekolah dan 6 orang guru kelas dan beberapa guru bidang studi

2. Uji beda hasil belajar siswa yang mengikuti paud dengan

\section{yang tidak mengikuti paud}

Untuk menguji apakah ada perbedaan hasil belajar siswa yang mengikuti pendidikan anak usia dini dengan ang tidak mengikuti pendidikan anak usia dini maka dilakukan pengujian dengan menggunakan uji-t

Pengujian tersebut dilakukan dengan tingkat signifikansi $\alpha=0.05$. Pengujian dapat dilakukan dengan membandingkan antara $t$ hitung dengan t table atau membandingkan nilai $\alpha=0.05$ dengan niliai sgnifikansi output SPSS dengan criteria keputusan :

$$
\text { Jika Sig }>\alpha=0.05 \text { : Ho }
$$

diterima atau $\mathrm{H} 1$ ditolak

$$
\text { Jika Sig }<\alpha=0.05: \mathrm{H} 1
$$

diterimaa atau Ho diterima

\section{Tabel.1}

Uji beda nilai mata pelajaran antara sisiwa yang mengikuti paud

\begin{tabular}{|c|c|c|c|}
\hline No & $\begin{array}{l}\text { Mata } \\
\text { Pelajaran }\end{array}$ & $\begin{array}{l}\mathrm{T} \\
\text { hitung }\end{array}$ & signifikansi \\
\hline 1 & PAI & 1.403 & 0.165 \\
\hline 2 & PKN & 0.219 & 0.827 \\
\hline 3 & $\begin{array}{l}\text { Bahasa } \\
\text { Indonesia }\end{array}$ & $-\overline{0.0111}$ & 0.912 \\
\hline 4 & Matematika & 0.037 & 0.970 \\
\hline 5 & IPA & -0.631 & 0.530 \\
\hline 6 & IPS & 0.772 & 0.443 \\
\hline 7 & SBK & -0.510 & 0.612 \\
\hline 8 & PJOK & 0.0101 & 0.920 \\
\hline 9 & $\begin{array}{l}\text { Bahasa } \\
\text { Inggris }\end{array}$ & -0.239 & 0.812 \\
\hline 10 & $\begin{array}{l}\text { Praktek } \\
\text { Sholat }\end{array}$ & 2.290 & $0.025^{*}$ \\
\hline 11 & Tahfis & 3.521 & $0.001 *$ \\
\hline 12 & Tahsin & 2.712 & $0.009 *$ \\
\hline 13 & $\begin{array}{l}\text { Jumlah } \\
\text { Keseluruhan }\end{array}$ & 6.362 & $0.000 *$ \\
\hline 14 & Rata-rata & 0.084 & 0.934 \\
\hline 15 & $\begin{array}{l}\text { Mata } \\
\text { Pelajaran } \\
\text { Praktek } \\
\text { Islam } \\
\text { (Praktek } \\
\text { sholat, } \\
\text { Tahfis, } \\
\text { Tahsin) }\end{array}$ & 3.246 & $0.002 *$ \\
\hline
\end{tabular}
dengan yang tidak mengikuti paud
Keterangan : $*$ = signifikan

Berdasarkan analisis diatas

maka dapat dilihat bahwa perbedaan hasil belajar antara siswa yang megikuti pendidikan anak usia dini dengan yang tidak mengikuti pendidikan anak usia dini signifikan pada mata pelajaran praktek sholat, tahfis dan tahsin. Itu menyebabkan jumlah keseluruhan mata pelajaran 
terbukti ada perbedaan hasil belajar yang signifikan antara siswa yang mengukuti pendidikan anak usia dini dengan yang tidak mengikuti pendidikan anak usia dini

\section{Uji beda hasil belajar siswa yang mengikuti RA, TK dengan yang tidak mengikuti paud}

Untuk menguji apakah ada perbedaan hasil belajar siswa yang mengikuti pendidikan anak usia dini RA, TK dengan yang tidak mengikuti pendidikan anak usia dini maka dilakukan pengujian dengan menggunakan uji-t

Pengujian tersebut dilakukan dengan tingkat signifikansi $\alpha=0.05$. Pengujian dapat dilakukan dengan membandingkan antara $\mathrm{t}$ hitung dengan $\mathrm{t}$ table atau membandingkan nilai $\alpha=0.05$ dengan niliai sgnifikansi output SPSS dengan criteria keputusan :

Jika Sig $>\alpha=0.05:$ Ho diterima atau $\mathrm{H} 1$ ditolak

Jika Sig $>\alpha=0.05:$ H1 diterimaa atau Ho diterima

$\mathrm{Ha}=\mathrm{b} 1 \neq \mathrm{b} 3 \neq \mathrm{b} 4$, artinya ada perbedaan hasil belajar agama islam siswa antara siswa yang sebelum memasuki sekolah dasar tidak mengikuti pendidikan anak usia dini, yang mengikuti pendidikan anak usia dini TK dengan yang mengikuti pendidikan anak usia dini RA

Tabel.2

Uji beda nilai mata pelajaran antara sisiwa yang mengikuti paud dengan yang tidak mengikuti paud

\begin{tabular}{|l|l|l|l|}
\hline No & $\begin{array}{l}\text { Mata } \\
\text { Pelajar } \\
\text { an }\end{array}$ & T hitung & signifikansi \\
\hline 1 & PAI & 1.216 & 0.303 \\
\hline 2 & PKN & 2.176 & 0.122 \\
\hline 3 & $\begin{array}{l}\text { Bahasa } \\
\text { Indone } \\
\text { sia }\end{array}$ & 0.194 & 0.824 \\
\hline 4 & $\begin{array}{l}\text { Matem } \\
\text { atika }\end{array}$ & 0.888 & 0.416 \\
\hline 5 & IPA & 0.705 & 0.498 \\
\hline 6 & IPS & 0.341 & 0.712 \\
\hline 7 & SBK & 0.713 & 0.494 \\
\hline 8 & PJOK & 1.219 & 0.302 \\
\hline 9 & $\begin{array}{l}\text { Bahasa } \\
\text { Inggris }\end{array}$ & 0.103 & 0.903 \\
\hline 10 & $\begin{array}{l}\text { Prakte } \\
\text { k } \\
\text { Sholat }\end{array}$ & 3.282 & $0.044^{*}$ \\
\hline 11 & Tahfis & 7.529 & $0.001^{*}$ \\
\hline 12 & Tahsin & 4.681 & $0.013^{*}$ \\
\hline 13 & $\begin{array}{l}\text { Jumlah } \\
\text { Keselu } \\
\text { ruhan }\end{array}$ & 20.312 & $0.000^{*}$ \\
\hline 14 & Rata- & 0.252 & 0.778 \\
\hline
\end{tabular}




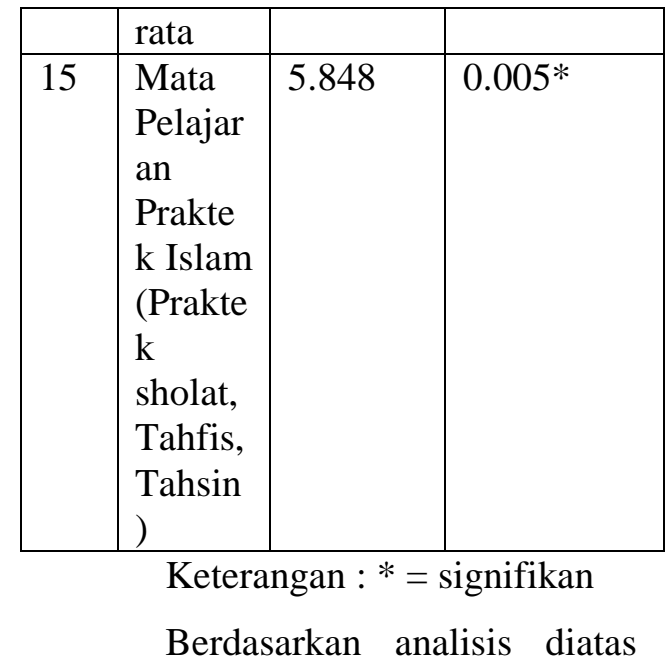

maka dapat dilihat bahwa perbedaan hasil belajar antara siswa yang megikuti pendidikan anak usia dini RA, TK dengan yang tidak mengikuti pendidikan anak usia dini signifikan pada mata pelajaran praktek sholat, tahfis dan tahsin. Itu menyebabkan jumlah keseluruhan mata pelajaran terbukti ada perbedaan hasil belajar yang signifikan antara siswa yang mengukuti pendidikan anak usia dini RA, TK dengan yang tidak mengikuti pendidikan anak usia dini

\section{E. KESIMPULAN DAN SARAN}

\subsection{Kesimpulan}

Dari hasil penelitian yang ada maka dapat disimpulkan bahwa:
1. Jika dilihat hasil belajar siswa secara keseluruhan maka tidak ada perbedaan hasil belajar siswa antara siswa yang sebelum masuk sekolah dasar tidak mengikuti pendidikan anak usia dini dengan siswa yang sebelum masuk sekolah dasar mengikuti pendidikan anak usia dini.

2. Jika dilihat hasil belajar siswa yang berkaitan dengan mata pelajaran agama islam terbukti bahwa ada perbedaan hasil belajar agama islam antara siswa yang sebelum memasuki sekolah dasar tidak mengikuti pendidikan anak usia dini, siswa yang sebelum memasuki sekolah dasar mengikuti pendidikan anak usia dini Taman Kanak-Kanak dengan siswa yang sebelum masuk sekolah dasar mengikuti pendidikan anak usia dini Raudhatul Athfal. Hal ini terlihat dari perbedaan hasi belajar yang signifikan pada mata pelajaran praktek islam 
seperti praktek sholat, tahsin

qur'an dan tahfiz qur'an.

\subsection{Saran}

Saran yang dapat

diberikan kepada berbagai pihak yaitu :

1. Saran kepada sekolah yaitu sebaiknya untuk sekolah dasar islam terpadu yang mata pelajarannya lebih kearah ilmu keislaman ada baiknya ketika menerima siswa lulusan TK atau bahkan tidak punya pengalaman menjalani pendidikan anak usia dini agar lebih diperhatikan pada pelajaran-pelajaran praktek islam seperti praktek sholat, tahsin qur'an dan tahfiz qur'an. Hal ini adalah upaya agar tidak ada perbedaan hasil belajar yang signifikan antara anak yang mengemban pendidikan anak usia dini di RA, TK bahkan yang tidak punya pengalaman melewati pendidikan anak usia dini.

2. Saran kepada orang tua sebaiknya ketika ingin memasukkan anak ke sekolah dasar islam terpadu sebaiknya membekali anak terlebih dahulu tentang ilmuilmu islam agar ketika anak menjalani masa sekolah, hasil belajar anak tidak berbeda jauh dengan temantemannya

\section{DAFTAR PUSTAKA}

Arifin, Z. (2012). Evaluasi Pembelajaran. Jakarta:

Direktorat Jendral Pendidikan Islam Kementrian Agama.

Arikunto, S. (2006). Metodelogi penelitian. Yogyakarta: Bina Aksara

Iskandar. (2009). Psikologi Pendidikan Sebuah Orientasi Baru. Ciputat: Gaung Persada Press.

Purwanto, M. N. (2005).

Prinsip-Prinsip dan

Teknik Evaluasi

Pengajaran. Bandung:

Rosdakarya.

Republik Indonesia. 2003. 
Undang-Undang

Sistem Pendidikan

Nasional. Jakarta :

Sekretariat Negara

Republik Indonesia. 2003. Undang-

Undang No 20 Sistem

Pendidikan Nasional.

Jakarta : Sekretariat Negara

Republik Indonesia. 1989. Undang-

Undang No 2Sistem

Pendidikan Nasional. Jakarta:

Sekretariat Negara

Republik Indonesia. 2010.

Peraturan Pemerintah No 17.

Jakarta: Sekretariat Negara

Rosnita. (2007). Evaluasi

Pendidikan. Bandung:

Ciptapustaka Media.

Sudjana, N. (2005). Penilaian

Hasil Proses Belajar

Mengajar. Bandung: PT.

Remaja Rosdakarya.

Sugiyono, 2007, Statistika

Untuk Penelitian,

Cetakan Keduabelas.

Bandung : Alfabeta

2012.

Metode Penelitian

Kuantitatif Kualitatif dan R\&D. Bandung:

Alfabeta.

Usman, Husaini, 2006. Pengantar Statistika. Jakarta : Bumi

Aksara 
